\title{
ВЕЛИКИ ДОПРИНОС СРПСКОЈ И ФРАНКОРОМАНИСТИЧКОЈ ТРАДУКТОЛОГИЈИ
}

\author{
Mladenović, B. i Samardžija, T. (2019). Le bon mot: prevođenje \\ tekstova sa srpskog na francuski sa gramatičkim objašnjenjima. \\ Beograd: Filološki fakultet Univerziteta u Beogradu.
}

У издању Филолошког факултета Универзитета у Београду почетком 2019. објављен је својеврсни уџбеник превођења са српског на француски језик ауторки Брижит Младеновић и Татјане Самарџије. Књига је плод дугогодишњег искуства ауторки у педагошком раду са студентима Катедре за романистику Филолошког факултета, а намењена је превасходно србофоним студентима завршне године студија, то јест будућим наставницима француског као страног језика, односно преводиоцима. Рецензенти ове публикације су еминентни професори франкороманистике у Србији - проф. др Снежана Гудурић и проф. др Михаило Поповић. Основни циљ овог приручника, према речима самих ауторки, јесте пружање неопходних преводилачких вештина студентима француског језика, али и увида у најзначајнија граматичка правила из синтаксе француске просте и сложене реченице.

Дати смо приказ замислили као субјективан, будући да из угла студената докторских академских студија износимо виђење књиге, за које сматрамо да би, потенцијално, било блиско српским студентима француског језика свих нивоа студија, од основних и мастер студија, до доктораната који улазе у сферу научно-истраживачког рада.

\footnotetext{
* andjela.vasiljevic.ue@gmail.com

** Овај приказ настао је у оквиру рада на пројекту „Динамика структура савременог српског језика“, евиденциони број 178014, финансираног од стране Министарства просвете, науке и технолошког развоја Републике Србије.
} 
Анђела Д. Васиљевић

Но, кренимо од саме структуре ове публикације. Наиме, мишљења смо да је изузетно тешко именовати дату књигу као приручник или уџбеник превођења, будући да она превазилази и по својој структури и садржини класичне уџбенике граматике или превођења, у којима се обично инсистира на теоријским поставкама, а мање на практичној примени знања. Имајући у виду да се страни језик, односно његове лексичко-семантичке и синтаксичке структуре најбоље и најефикасније усвајају у контексту, ауторке Б. Младеновић и Т. Самарџија полазе од конкретних текстова савремених српских писаца, пружајући истовремено предлог превода на француски језик, детаљна граматичка објашњења, али и занимљиве глосаре из најразличитијих сфера живота.

Књига је подељена у двадесет поглавља, која су у ствари одломци из дела српских писаца XX и XXI века. Већина датих текстова, како сазнајемо у Предговору, јесу предлошци са испита из Савременог француског језика на завршним годинама основних студија, то јест писменог дела овог испита (thème). Граматичке партије у потпуности прате програм из предмета Синтакса сложене реченице у француском језику са четврте године студија, а комплементарне су и са другим језичким предметима, од Синтаксе глагола и глаголских времена до Лексикологије и семантике француског језика.

У књизи налазимо одломке из текстова савремених српских писаца, као што су Меша Селимовић, Гордана Ћирјанић, Драган Великић, Светлана Велмар-Јанковић, Филип Давид, Добрило Ненадић, Павле Угринов, Вида Огњеновић, Нада Варничић-Донжон, Милован Данојлић и други. Пре свега, реч је о делима која углавном нису преведена на француски језик, па је то уједно одлична прилика да се студенти упознају са типом текстова какве би у будућности могли преводити. Осим тога, лексичка поља обрађена у књизи везана су за најшире домене друштвеног живота и природне средине: живи свет, елементарне непогоде, загађење животне средине, путовања, миграције, различите домене уметности (музика, сликарство, архитектура), здравство, правду, те личне ставове и осећања.

Текстови су поређани према тежини, од најједноставнијих до најзахтевнијих. Структурно гледано, свако од двадесет поглавља ове књиге концизно је и сажето представљено. Најпре је дат српски текст, а затим и француски, у преводу Б. Младеновић. Бројеви који се ја- 
ВЕЛИКИ ДОПРИНОС СРПСКОЈ И ФРАНКОРОМАНИСТИЧКОЈ ...

вљају у преводу јесу својеврсна упутница која води ка синтаксичким, али лексичким коментарима у другом делу поглавља, које потписује Т. Самарџија. Свака од датих конструкција обрађена је и са теоријске и са практичне тачке гледишта. Исцрпно су анализиране структуре свих зависних реченица француског језика: односне, изричне, зависно-упитне, прилошке (темпоралне, каузалне, последичне, концесивне, адверзативне, хипотетичке, намерне, поредбене), заједно са комбинацијама глаголских времена која се у њима срећу. У коментарима се обрађују како лични, тако и нелични глаголски облици (инфинитиви, партиципи, герунд), те имперсоналне, фактитивне конструкције, аспектуалне перифразе, случајеви инверзије субјекта и предиката, слободни индиректни говор, итд.

Приликом анализе одређених типова зависних реченица даје се велики број синонимних везника, са детаљно објашњеним нијансама значења и различитим синтаксичким правилима. Нарочита пажња посвећена је глаголским начинима и временима која се комбинују са сваким од датих везника. Примера ради, у поглављу 7.13. (стр. 112) налазимо детаљну синтаксичку анализу темпоралног везника за изражавање антериорности avant que. Истовремено се предлажу његови синоними en attendant que, d'ici à ce que, le temps que, jusqu'à ce que, чија је заједничка особина обавезна употреба француског субјунктива/ конјунктива. Осим тога, анализиране су и неке друге специфичности, као што је то случај са факултативним коришћењем експлетивног nе или (не)слагањем времена. На тај начин предлажу се сродне синтаксичке и значењске конструкције, а захваљујући систему упутница, какве налазимо у речничким чланцима, читалац лако и брзо може доћи до конструкција блиског значења и додатних комплементарних објашњења у другим поглављима (нпр. V . aussi le commentaire 19/ - В. йакође коменйар 19).

Примера ради, за српске студенте посебно би могли бити значајни коментари о превођењу прошлих времена српског језика на француски, будући да је у систему прошлих времена нашег језика данас перфекат доминантан. С друге стране, у француском се користе, поред перфекта, имперфекат, плусквамперфекат, те аорист, нарочито у писаним текстовима вишег језичког регистра. Још једна значајна разлика, када је о синтакси глаголских облика реч, односи се на појам глаголског аспекта. Наиме, српски, као словенски језик, 
Анђела Д. Васиљевић

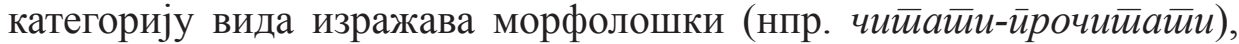
док француски језик разлику у аспекту изражава граматички помоћу глаголских времена, односно опозиције аористних и имперфекатских завршетака (нпр. опозиција аорист Je lus - имперфекат Je lisais). Још већа потенцијална потешкоћа за студенте јесу случајеви у којима се српски имперфективни глаголи преводе помоћу француског перфекта, којег иначе одликује категорија свршености, како је на пример детаљно илустровано у коментару 12.9. (стр. 184). Имајући у виду да студенти често греше при преводу оваквих структура, ауторке посебно наглашавају дуративно-перфективни карактер процеса израженог у примеру Паgао је [снеї] чийаву ноћ/ Elle [la neige] n'a cessé de tomber toute la nuit, што објашњава избор француског перфекта, а не имперфекта у датом преводу.

Иако је бројчано највећи део коментара посвећен синтаксичким конструкцијама, нису занемарене ни семантичке појединости. Добар преводилац увек мора имати на уму полисемичну структуру одређених лексема, како у матерњем, тако и у страном језику. Из тог разлога, кључно је да се при превођењу текстова са српског на француски језик адекватно анализирају различите значењске особености лексема, на шта ауторке у више наврата указују. Узмимо за пример семантичку структуру српске лексеме околина, коју одликује висок степен вишезначности, те се у коментару 8.8. (стр. 127) детаљно обрађују њена различита значења: 1. скуй љуgи, ояносно ярушивво у којем живимо; 2. скуи ирирояних елеменайа и йојава које нас окружују, ирирояна среgина; 3. околни йреgео, иростиор. Будући да је у оригиналном тексту лексема околина употребљена у првом значењу, јер упућује на комуникацију књижевног лика са људима из свог окружења, потребно је превести дату реч француском entourage, а не лексемама блиског значења, које се односе на животну средину (фр. environnement), односно физички простор који окружује одређено место (фр. alentours, environs).

Горепоменути случајеви неподударности у лексичким и синтаксичким структурама датих језика представљају значајан извор потешкоћа за српске студенте, па је у том смислу допринос ове књиге још већи. Пошто се теоријске поставке објашњавају конкретним примерима, овакав је приступ веома иновативан и интерактиван, те у складу са актуелним дидактичким теоријама у настави страних језика, које се односе на неопходност учења страног језика у контексту. 
ВЕЛИКИ ДОПРИНОС СРПСКОЈ И ФРАНКОРОМАНИСТИЧКОЈ ...

Наиме, теоријска објашњења поткрепљена су и репрезентативним примерима датог језичког феномена, углавном преузетих из велике базе француских текстова - Frantext. Самим тим, на студентима је да изаберу да ли ће индуктивном методом на основу примера сами доћи до теоријског правила или се пак определити за класични дедуктивни приступ. У том смислу, овај уџбеник/ приручник превођења може се користити као комплементаран предавањима и вежбама у оквиру студијског програма, али може бити погодан и за самостални рад.

Поред савладавања синтаксичких особености страног језика, уочавање различитих случајева полисемије и других лексичко-семантичких механизама (метафоре, метонимије, елипсе, и сл.) представља нужни део сазревања будућих преводилаца, те овим језичким феноменима ауторке посвећују посебну пажњу у књизи. Избор одређеног преводног еквивалента често је у спрези са регистром, стилом којим је текст написан, те неким лингвокултуролошким разликама. Такође, у коментарима се анализирају и еквиваленти одређених идиоматских израза, који се најчешће не могу превести дословно, те стога представљају изазов у настави и учењу страног језика. У глосарима се налазе и бројне колокације, тако да се читалац може упознати са неким од најчешћих комбинација речи, али и увидети у којим је контекстима употреба синонимних лексема неприхватљива, што је важан и захтеван корак у процесу усвајања лексике страног језика.

Иако је ова публикација првенствено намењена студентима првог циклуса студија, желимо да истакнемо да је она једнако информативна и за студенте другог и трећег циклуса, односно младе научне раднике. Наиме, дата књига може бити полазна станица за све компаратисте - проучаваоце сличности и разлика у структурама француског и српског језика. На овом месту они могу наћи неисцрпан извор инспирације за даља контрастивна истраживања. Имајући у виду да се ауторке у својим коментарима синтаксичких и семантичких структура позивају на стручњаке из романистичке, али и српске лингвистике, библиографске референце садрже значајне изворе за даљи рад. Цитиране су теоријске поставке еминентних аутора као што су J.-М. Adam, J.-C. Anscombre, R. Barthes, C. Fuchs, P. Le Goffic, M. Riegel, L. Tesnière и многи други. Све то, коначно, доприноси већој информативности текста, а читаоце, односно младе научне раднике, подстиче на даља истраживања у овом домену. 
Анђела Д. Васиљевић

Као последње, згодно је поменути да индекс, који се налази на самом крају публикације, омогућује брзо претраживање, како граматичких термина, тако и лексема. Стога јој читаоци не морају нужно приступати линеарно. Поглавља се дакле могу читати независно једна од других, према власититим потребама и афинитетима, а да при томе глобално разумевање не буде нарушено.

Превођење било ког типа писаних текстова на нематерњи језик представља, уз симултано превођење, несумњиво најтежи сегмент учења страног језика. Овај сложени процес захтева од студената, будућих наставника и преводилаца, дуго и минуциозно усавршавање на неколико језичких планова: морфолошком, лексичко-семантичком, синтаксичком, прагматичком, те стилистичком. Све су то различити домени науке о језику којима студент у идеалном случају треба да уравнотежено влада како би једнога дана постао успешан преводилац. Књига Le bon mot : prevođenje tekstova sa srpskog na francuski sa gramatičkim objašnjenjima управо представља синтезу граматичких структура француског језика, не запостављајући при том лексику из различитих домена живота, специфичне идиоматске изразе и друге појединости. Из свега претходно реченог произлази да дата књига пружа драгоцен допринос дидактици наставе француског као страног језика, али и традуктологији, односно примењеној лингвистици у ширем смислу. Колико нам је познато, она је за сада једина публикација те врсте у нашој франкороманистичкој и лингводидактичкој средини. 